\title{
Haemolytic-uraemic Syndrome: Survival after Prolonged Oliguria
}

\author{
P. SHARPSTONE, R. G. EVANS, M. O'SHEA, L. ALEXANDER, and H. A. LEE* \\ From King's College Hospital and Medical School, London S.E.5
}

Since the original definition of the haemolyticuraemic syndrome by Gasser et al. (1955), there have been many reports of infants and children suffering from this distinctive combination of haematological and renal disorders. The clinical features usually include diarrhoea and vomiting of acute onset, succeeded by pallor and sometimes bruising or petechiae. Oliguria is common but its duration is variable and hypertension occurs in some cases. The blood picture shows a 'microangiopathic haemolytic anaemia' (Brain, Dacie, and Hourihane, 1962), with bizarre, distorted, and fragmented red blood cells, burr cells, poikilocytosis, anisocytosis, spherocytosis, and polychromasia. The direct Coombs test is negative, the reticulocyte count is raised, and thrombocytopenia of variable degree is often present. Haemoglobinaemia and haemoglobinuria occur in the more severe cases. The urine contains protein and red blood cells, and the blood urea is raised in proportion to the degree of oliguria. Comprehensive reviews include those of Lieberman et al. (1966), Piel and Phibbs (1966), and Habib, Mathieu, and Royer (1967).

The mortality of 150 reported cases was $43 \%$ (McLean, Jones, and Sutherland, 1966), death resulting usually from uraemia or its complications. Prolonged anuria or oliguria in this disease is considered of sinister significance, and we, therefore, report here 3 patients with the haemolytic-uraemic syndrome who recovered, with the aid of dialysis, after periods of oliguria of 23,24 , and 15 days duration, respectively.

\section{Case Reports}

Case 1. This female infant, born prematurely at 32 weeks (birthweight $1.36 \mathrm{~kg}$.), progressed satisfactorily until June 30,1963, when at the age of 23 weeks she developed diarrhoea and vomiting. The following day she had

Received May 22, 1968.

^Present address: Renal Unit, St. Mary's Hospital, Portsmouth, Hants. a generalized convulsion and was admitted to hospital where examination showed her to be febrile $\left(38.3^{\circ} \mathrm{C}\right.$.), pale, and not dehydrated. $\mathrm{Hb}$ was $5.8 \mathrm{~g} . / 100 \mathrm{ml}$., red cells were hypochromic, there was some polychromasia, and platelets appeared normal on the film. She was treated with intravenous fluids, blood transfusion, and sulphonamides; but she continued to pass small watery motions, had a further convulsion, was noted to be anuric, and was transferred to King's College Hospital on July 5 . She then weighed $5.5 \mathrm{~kg}$., was oedematous, systolic blood pressure was $60 \mathrm{~mm}$. $\mathrm{Hg}$, the spleen was not palpable, and there was no focal neurological abnormality. Investigations showed $\mathrm{Hb}$ $7 \cdot 1 \mathrm{~g}$. $/ 100 \mathrm{ml}$., packed cell volume $21 \%$, mean corpuscular $\mathrm{Hb}$ concentration $30 \%$, the red blood cells showed increased polychromasia and some contracted and burr forms, platelets ample, white blood count $6000 \mathrm{cu} . \mathrm{mm}$., neutrophils $40 \%$. The blood urea was $250 \mathrm{mg}$. $/ 100 \mathrm{ml}$., sodium $131 \mathrm{mEq} / \mathrm{l}$., and potassium $6.1 \mathrm{mEq} / \mathrm{l}$. Stool culture showed no pathogenic organisms. The blood sulphonamide concentration was $17.5 \mathrm{mg} . / 100 \mathrm{ml}$., but no sulphonamide crystals were detected in bladder washings.

Complete anuria persisted until July 14, (Fig. 1) and thereafter her urine output remained below $50 \mathrm{ml}$. daily until July 22, when a slowly increasing diuresis occurred, followed 4 days later by a decline in the blood urea concentration. During this 23-day period of oliguria, 3 haemodialyses were carried out, and after the initial dialysis her blood urea never exceeded 200 mg. $/ 100 \mathrm{ml}$. The only complication of the dialyses was bleeding from the cannula sites, which was controlled by pressure dressings and blood replacement. Subsequent recovery of renal function was slow and at the time of discharge from hospital on October 7, her urine still contained protein and the blood urea was $56 \mathrm{mg} . / 100 \mathrm{ml}$. Hypertension $(200 / 120 \mathrm{~mm}$. $\mathrm{Hg}$ ), which had complicated the course of her illness, had remitted by then. An intravenous pyelogram (IVP), cystoscopy, and examination under anaesthetic showed aplasia of the right kidney and a congenital malrotation of the left kidney. The peripheral blood picture showed evidence of continuing haemolysis during the oliguric period, and blood transfusions were given with each dialysis. After the third week of illness a progressive slow rise in haemoglobin concentration occurred, reaching $12 \mathrm{~g} . / 100 \mathrm{ml}$. by the time of discharge. 


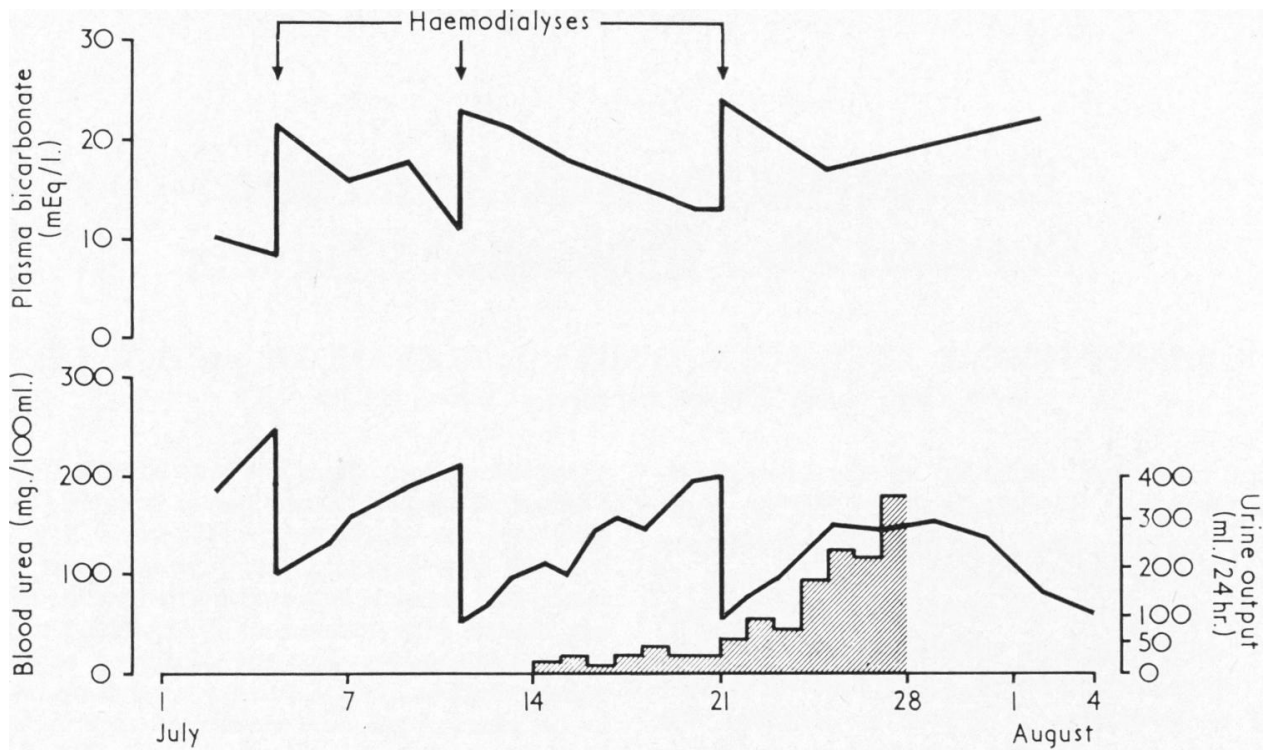

Fig. 1.-Course of the illness in Case 1.

At the most recent follow-up, $4 \frac{1}{2}$ years after the onset of her illness, she weighed $19 \cdot 8 \mathrm{~kg}$. (50th centile), her height was $97 \mathrm{~cm}$. (10th centile), and BP $110 / 70 \mathrm{~mm}$. $\mathrm{Hg}$. Investigation showed $\mathrm{Hb} 13.4 \mathrm{~g} . / 100 \mathrm{ml}$., blood picture normal, blood urea $32 \mathrm{mg} . / 100 \mathrm{ml}$., plasma creatinine $0.9 \mathrm{mg} . / 100 \mathrm{ml}$, creatinine clearance $72 \mathrm{ml} . / \mathrm{min}$. per 1.73 sq. m., urine protein $35 \mathrm{mg} . / 100 \mathrm{ml}$., and urine deposit normal.

Case 2. This 17-month-old female infant was admitted to hospital on September 28, 1967, with a history of the passage of frequent, small, loose, yellow stools for 3 days and vomiting for 1 day. She passed no urine during the next 2 days, had a convulsion, and was transferred to King's College Hospital on September 30, 1967. She was then afebrile, pale, and oedematous, had neither purpura nor splenomegaly, and no focal neurological signs. Her blood pressure was $90 / 60 \mathrm{~mm}$. $\mathrm{Hg}$ and her weight $\mathbf{9 . 8} \mathrm{kg}$. Investigations showed Hb 5.5 g. $/ 100 \mathrm{ml}$., PCV $17 \%$, MCHC $35 \%$, reticulocytes $5.6 \%$, WBC $11,400 /$ cu.mm., with $47 \%$ neutrophils, platelets $65,000 / \mathrm{cu} . \mathrm{mm}$. The blood film showed fragmentation and spherocytosis of about $10 \%$ of the red blood cells. The plasma contained free haemoglobin, and the direct Coombs test was negative. Urine (October 2) contained haemoglobin, red blood cells, white blood cells, and had a protein concentration of $440 \mathrm{mg} . / 100 \mathrm{ml}$. and a urea concentration of 580 mg. $/ 100 \mathrm{ml}$. Blood urea $400 \mathrm{mg} . / 100 \mathrm{ml}$., sodium 126, potassium $5 \cdot 3$, bicarbonate $9 \mathrm{mEq} / 1$., and serum bilirubin $1.8 \mathrm{mg}$. $/ 100 \mathrm{ml}$., with a negative direct Van den Berg reaction. Stool culture was negative for pathogens.

The progress of her illness is summarized in Fig. 2. Anuria lasted for 2 further days and was succeeded by a prolonged period of oliguria, the urine output exceeding $200 \mathrm{ml}$. per day for the first time on October 19. During this 24-day period of oliguria the uraemia was controlled with peritoneal dialysis for 6 hours daily for 17 days. The dialysis was complicated by an episode of bleeding from the catheter site associated with excessive heparin dosage, and by a puncture of the bladder which healed spontaneously. Blood transfusions were given and heparin was administered intravenously in a dose of between 5000 and 10,000 units daily, by two-hourly intravenous injection, from October 5 for 9 days. A rise in the platelet count from 69,000 to $181,000 /$ cu.mm. occurred within 24 hours of starting heparin. The signs of haemolysis regressed and an improvement in red cell morphology occurred more gradually. By October 12 only about $3 \%$ of the red blood cells were fragmented. During the course of her illness the spleen became palpable. Because of persisting oliguria, ACTH 15 units intramuscularly daily was started on October 18, and the following day a rapidly increasing diuresis started. The serum concentration of fibrinogen breakdown products (FBP), determined by the tanned red cell haemagglutination inhibition assay technique (Merskey, Kleiner, and Johnson, 1966), remained raised throughout the acute phase of the illness, and showed no evidence of response to heparin.

By the time of discharge from hospital on October 27, $\mathrm{Hb}$ was $9.9 \mathrm{~g} . / 100 \mathrm{ml}$., there were only occasional fragmented red cells in the blood film, the platelet count was $379,000 /$ cu.mm., the blood urea $26 \mathrm{mg} . / 100$ ml., and plasma creatinine $1 \mathrm{mg} . / 100 \mathrm{ml}$. The urine, however, still contained red blood cells and protein (257 mg./100 ml.). Her intravenous pyelogram was normal. 


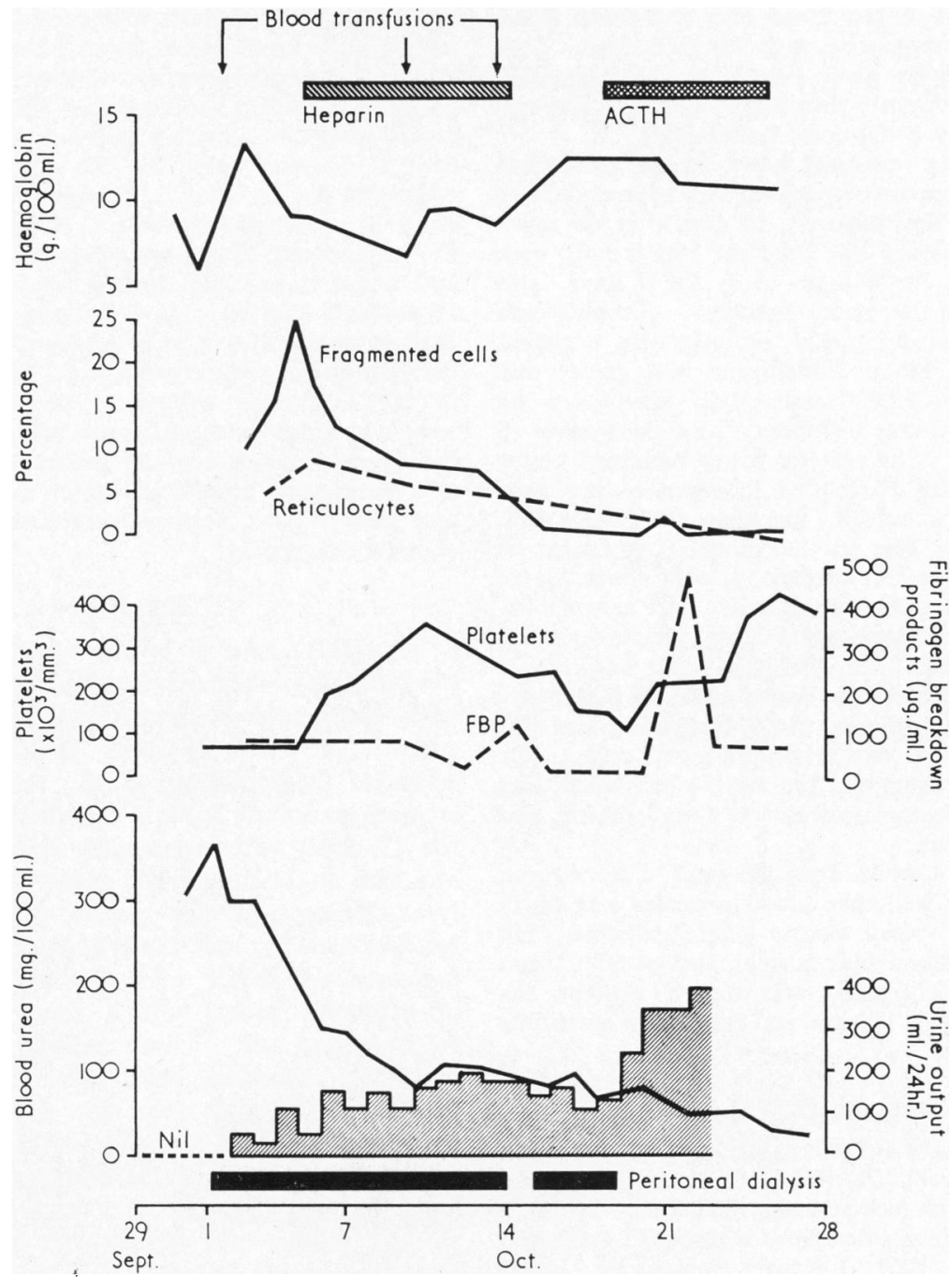

FIG. 2.-Course of the illness in Case 2.

At follow-up, 20 weeks after the start of her illness, the spleen was no longer palpable, her blood pressure was $128 / 74 \mathrm{~mm}$. $\mathrm{Hg}, \mathrm{Hb} 12.7 \mathrm{~g} . / 100 \mathrm{ml}$., with normal red cell morphology, platelet count 150,000/cu.mm., blood urea $29 \mathrm{mg} .100 \mathrm{ml}$., and blood creatinine $0.5 \mathrm{mg} . / 100 \mathrm{ml}$. The creatinine clearance was $67 \mathrm{ml} . / \mathrm{min}$. per 1.73 sq.m., the urine protein excretion was $400 \mathrm{mg} . / 24 \mathrm{hr}$., and the urine deposit was normal.

Case 3. This girl, aged 3 years 8 months, complained of abdominal pain on October 27, 1967, and the following day developed diarrhoea with 5-6 watery stools daily. Subsequently vomiting occurred, and she was admitted to hospital on November 2, 1967, at which time she had passed no urine for 24 hours. She was anaemic ( $\mathrm{Hb} 6.5 \mathrm{~g} . / 100 \mathrm{ml}$.$) , dehydrated, and had a palpable$ spleen. She was given intravenous fluids and blood transfusion, was found to be oliguric (urine output $30 \mathrm{ml}$. per day), and on November 4 she was transferred to King's College Hospital. She was then pale, puffy, and afebrile, and weighed $15.7 \mathrm{~kg}$. There was no purpura, blood pressure was $110 / 75 \mathrm{~mm}$. $\mathrm{Hg}$, and the spleen was enlarged to $2 \mathrm{~cm}$. below the costal margin. Investigation showed $\mathrm{Hb} 11.6 \mathrm{~g} . / 100 \mathrm{ml}$., reticulocytes $8 \%$, platelets $55,000 /$ cu.mm., white blood count 13,400 cu.mm., with $76 \%$ neutrophils. The blood film showed marked fragmentation and polychromasia of the red cells. There was no free plasma haemoglobin. Her blood urea was $410 \mathrm{mg} . / 100 \mathrm{ml}$., sodium 127, potassium $4 \cdot 2$, bicarbonate $11 \mathrm{mEq} / \mathrm{l}$. The urine protein concentration was $488 \mathrm{mg} . / 100 \mathrm{ml}$., the urea concentration $840 \mathrm{mg} . / 100 \mathrm{ml}$., and the urine deposit contained 
moderate numbers of red blood cells and white blood cells. Stool culture was negative for pathogens. Culture of a throat swab grew $\beta$-haemolytic streptococci and the antistreptolysin-0 titre was $\mathbf{7 5}$ units on November 10 , rising to over 400 units 7 days later.

Her urine output remained below $50 \mathrm{ml}$. daily until November 7, and thereafter progressively rose, exceeding $300 \mathrm{ml}$. a day on November 11, 15 days after the onset of her illness. During this time she was treated with peritoneal dialysis for 8 hours daily for 7 days, with effective control of the blood chemistry. Troublesome bleeding from the peritoneal catheter site occurred on 2 occasions. Blood transfusion was given, and heparin 10,000 to 12,000 units daily was given by continuous intravenous injection from November 5 to November 12. The platelet count remained below $50,000 /$ cu.mm. until November 9, when a slow progressive increase occurred, reaching 140,000/cu.mm. on November 13. The red cell morphology improved progressively, and on November 16 , only about $2 \%$ of the red blood cells were abnormal. The serum concentration of fibrinogen breakdown products never exceeded $24 \mu \mathrm{g} . / \mathrm{ml}$. On discharge from hospital on November 24 investigations showed $\mathrm{Hb} 10.9 \mathrm{~g} . / 100 \mathrm{ml}$, reticulocytes $2 \%$, platelets $216,000 / \mathrm{cu}$.mm., and the blood film showed a few fragmented red cells. The urine protein excretion was $760 \mathrm{mg}$. $/ 24 \mathrm{hr}$., blood urea $63 \mathrm{mg} . / 100 \mathrm{ml}$., plasma creatinine $1.1 \mathrm{mg}$. $/ 100 \mathrm{ml}$., and the IVP was normal.

At follow-up, 19 weeks after the start of her illness, she was clinically well, her blood pressure was $90 / 70$ $\mathrm{mm}$. $\mathrm{Hg}$, and the spleen was no longer palpable. $\mathrm{Hb}$ $12.0 \mathrm{~g} . / 100 \mathrm{ml}$., blood film normal, and platelet count $201,000 / \mathrm{cu} . \mathrm{mm}$. The urine was free of protein, the blood urea was $29 \mathrm{mg}$. $/ 100 \mathrm{ml}$., and the plasma creatinine $0.7 \mathrm{mg} . / 100 \mathrm{ml}$.

\section{Techniques of Dialysis}

The haemodialyses (Case 1) were carried out using one coil of the Kolff Twin-Coil artificial kidney, and with the patient on continuously recording weighing scales, by our previously described technique (Anderson, Lee, and Stroud, 1965; Lee and Sharpstone, 1966). The inferior vena cava was cannulated via both long saphenous veins at the groin and the cannulae were kept patent between dialyses by the continuous infusion of heparinized saline solution.

The technique of peritoneal dialysis differed from the standard adult method (Maxwell et al., 1959) in the following respects. A paediatric size catheter ('Trocath', McGaw) was used. The exchange volumes $(300 \mathrm{ml}$. Case 2, and $500 \mathrm{ml}$. Case 3) were measured by weight change of the dialysate containers which were suspended from a spring balance. To ensure constant temperature of the dialysate this was warmed en route to the patient by passage through a coil of plastic tubing (R66 blood warmer, Baxter Laboratories Ltd). in a thermostatically controlled water bath at $40^{\circ} \mathrm{C}$. The patients were weighed two-hourly during the dialyses.

The peritoneal equilibration time was 15 minutes, and this short period coupled with the relatively large sur- face area of the infant peritoneum resulted in excess removal of water over sodium (Moriarty and Parsons, 1966), with the production of hypernatraemia (plasma sodium $152 \mathrm{mEq} / 1$. ) in Case 2 . This was corrected by substituting $5 \%$ dextrose solution for $50 \mathrm{ml}$. of each litre of dialysate, reducing the dialysate sodium concentration to $134 \mathrm{mEq} / \mathrm{l}$. Dialysate containing $1 \cdot 36 \%$ dextrose removed $200-400 \mathrm{ml}$. of fluid each day from the patients and allowed an adequate oral dietary intake and blood transfusion during the periods of oliguria. Hypertonic dialysis, required initially in Case 2 to correct overhydration, was achieved by increasing the dialysate glucose concentration to $2 \cdot 36 \%$ by the addition of $50 \%$ dextrose solution. Prophylactic antibiotics were not added to the dialysate which remained sterile throughout. Changing the catheters at the first sign of inflammation around the entry wounds, and in any case after 5 days, perhaps contributed to the absence of peritoneal sepsis.

\section{Discussion}

Though at least 40 of the reported patients with the haemolytic-uraemic syndrome have been treated with peritoneal or haemodialysis, there are few reports of recovery after prolonged anuria or oliguria. McQuiggan et al. (1965) successfully treated an infant aged 4 months, who was anuric for 17 days, with peritoneal dialysis for 16 days; and also an 11-month-old infant with 2 haemodialyses during a 20-day period of oliguria. Moorhead, Edwards, and Goldsmith (1965) reported a 6-month-old infant who recovered after 14 days of oliguria, during which time 3 haemodialyses were carried out. These cases, together with the 3 patients described here, serve to emphasize that prolonged oliguria does not necessarily indicate irreversible renal damage, and that the current availability of dialysis techniques, which are safe and effective in infants and small children, should reduce further the previously noted decreasing mortality of this disease (Gianantonio et al., 1964).

The renal lesion in the haemolytic-uraemic syndrome is variable, but 4 main histological patterns emerge (Lieberman et al., 1966; Habib et al., 1967)-bilateral cortical necrosis, local or widespread glomerular necrosis, often associated with fibrinoid necrosis of the afferent arterioles, microthrombi in glomerular capillaries, and proliferation of glomerular endothelial and epithelial cells. In other renal disease characterized by glomerular involvement, oliguria of more than a few days duration usually indicates extensive irreversible glomerular damage and a fatal outcome (Merrill, 1957); and indeed in many of the reported fatal cases of the haemolytic-uraemic syndrome, necropsy has revealed lesions such as bilateral cortical necrosis or extensive glomerular necrosis of such 
severity that recovery of useful renal function could not have occurred. However, other patients dying of uraemia have had less severe renal lesions at necropsy, and Habib et al. (1967) have pointed out the absence of correlation between the initial anuria and the type of renal lesion.

It is possible that suppression of urine in some patients could result from potentially reversible tubular dysfunction rather than from widespread obliteration of glomeruli (Boen, 1965). The haemoglobinaemia and haemoglobinuria, which occur in some cases (e.g. Case 2), could, in itself, be responsible for acute renal failure. Though histologically tubular necrosis is rarely marked in the haemolytic-uraemic syndrome unless glomerular damage is severe (Lieberman et al., 1966), in other varieties of acute oliguric renal failure histological abnormality of the tubules is often insignificant (Brun and Munck, 1957).

In the 14 previously reported patients in whom heparin has been used, an apparently favourable response has been noted in 11 (Hitzig, 1964; Kibel and Barnard, 1964; Künzer and Aalam, 1964; Desmit et al., 1965; Piel and Phibbs, 1966; Dacie, 1967; Habib et al., 1967), the most constant result being a prompt rise in the platelet count. In our Case 2, the platelet count rose from 69,000 to $181,000 /$ cu.mm. within 24 hours of starting heparin, and a decline in the percentage of fragmented cells and of reticulocytes in the blood started at the same time. Despite this improvement, a raised blood concentration of fibrinogen breakdown products was detected throughout the period of therapy. In Case 3 no such dramatic result was observed, though the platelet count rose progressively from 50,000 to $140,000 /$ cu.mm. during the 8 days of treatment. The use of heparin requires careful laboratory control to avoid under- or overdosage. In our patients it was administered by 2 -hourly intravenous injection or continuous intravenous infusion and thrombin clotting times were measured daily. The heparin dose was adjusted so that the thrombin clotting time was prolonged to at least twice the control value at 12 seconds, and no greater than 120 seconds. Experience in this laboratory has shown that this range indicates a plasma heparin concentration of between 0.125 and $1.0 \mathrm{mg} . / 100 \mathrm{ml}$. Despite this control, both patients suffered from bleeding episodes which necessitated the withdrawal of heparin. Our conclusions on the role of heparin in the treatment of the haemolyticuraemic syndrome must echo those of most previous authors, that though its value is as yet unproven the evidence at present merits its further trial.
The rationale for the use of heparin is based upon evidence that the haemolytic anaemia and thrombocytopenia result from damage to red cells and utilization of platelets by intravascular coagulation. Brain et al. (1962) related the microangiopathic haemolytic anaemia in a variety of clinical conditions to disease of small vessels rather than to uraemia; and in experimentally induced intravascular thrombosis it has been shown that the degree of haemolysis relates to the extent of the thrombi, and that peak levels of plasma haemoglobin coincide with the release of fibrin breakdown products (Brain and Beck, 1965; Brain and Hourihane, 1967; Brain, Esterly, and Beck, 1967; Regoeczi, Rubenberg, and Brain, 1967). Clinical evidence for the occurrence of disseminated intravascular coagulation is provided by the increased concentration of fibrinogen breakdown products in Case 2, and by the response of the platelet count to heparin.

The administration of ACTH to Case 2 was followed within 24 hours by the onset of diuresis. Most previous authors, however, have found corticosteroids to be without benefit, and we are unable to say whether the result with ACTH in this one patient was anything but coincidental.

Despite intensive investigation of many patients the aetiology of the haemolytic-uraemic syndrome remains obscure. Our Case 3 provided good evidence of an antecedent streptococcal infection, but this association has only rarely been recorded before (Brain, 1963). Other agents such as vaccination (Monnens and Retera, 1965) and virus infection (Gianantonio et al., 1964; Glasgow and Balduzzi, 1965) have occasionally been incriminated, and it seems likely that the aetiology of this condition will prove to be multifactorial.

\section{Summary}

Two infants and one child with the haemolyticuraemic syndrome survived after 23, 24, and 15 days, respectively, of oliguria. Haemodialysis in one patient and peritoneal dialysis in the others effectively and safely controlled the uraemia and allowed adequate blood replacement and dietary intake during the oliguric phase. Heparin treatment was given to 2 patients and was associated with a dramatic increase in the platelet count in one. Good evidence of a proceeding $\beta$-haemolytic streptococcal infection was obtained in one patient.

We are grateful to Prof. J. Anderson, Dr. C. E. Stroud, Dr. V. Parsons, and Dr. T. P. Mann for permission to report these patients and for their helpful advice. 


\section{REFERENCES}

Anderson, J., Lee, H. A., and Stroud, C. E. (1965). Haemodialysis in infants and small children. Brit. med. F., 1, 1405.

Boen, S. T. (1965). Discussion. Proc. Symp. Europ. Dialysis Transpl. Ass., 2, 75.

Brain, M. C. (1963). Microangiopathic haemolytic anaemia. D. M. Thesis, Oxford University.

- , and Beck, E. A. (1965). Relationship of intravascular coagulation and intravascular haemolysis. Clin. Res., 13, 268.

-, Dacie, J. V., and Hourihane, D. O'B. (1962). Microangiopathic haemolytic anaemia: the possible role of vascular lesions in pathogenesis. Brit. F. Haemat., 8, 358.

- Esterly, J. R., and Beck, E. A. (1967). Intravascular haemolysis with experimentally produced vascular thrombi. ibid., 13, 868 .

- and Hourihane, D. O'B. (1967). Microangiopathic haemolytic anaemia: the occurrence of haemolysis in experimentally produced vascular disease. ibid., 13, 135.

Brun, C., and Munck, O. (1957). Lesions of the kidney in acute renal failure following shock. Lancet, 1, 603.

Dacie, J. V. (1967). The Haemolytic Anaemias, 2nd ed., p. 850. Churchill, London.

Desmit, E. M., Hart, H. C., Helleman, P. W., and Tiddens, H. A. W. M. (1965). Heparin treatment in a patient with haemolytic uraemic syndrome. Proc. Symp. Europ. Dialysis Transpl. Ass., 2, 68.

Gasser, C., Gautier, E., Steck, A., Siebenmann, R. E., and Oechslin, R. (1955). Hämolytisch-urämische Syndrome; bilaterale Nierenrindennekrosen bei akuten erworbenen hämolytischen Anämien. Schweiz. med. Wschr., 85, 905.

Gianantonio, C., Vitacco, M., Mendilaharzu, F., Rutty, A., and Mendilaharzu, J. (1964). The hemolytic-uremic syndrome. F. Pediat., 64, 478.

Glasgow, L. A., and Balduzzi, P. (1965). Isolation of Coxsackje virus group A, type 4, from a patient with hemolytic-uremic syndrome. New Engl. F. Med., 273, 754.

Habib, R., Mathieu, H., and Royer, P. (1967). Le syndrome hémolytique et urémique de l'enfant. Nephron, 4, 139.
Hitzig, W. H. (1964). Therapie mit Antikoagulantien in der Pädiatrie. Helv. paediat. Acta, 19, 213.

Kibel, M. A., and Barnard, P. J. (1964). Treatment of acute haemolytic-uraemic syndrome with heparin. Lancet, 2, 259.

Künzer, W., and Aalam, F. (1964). Treatment of the acute haemolytic-uraemic syndrome with heparin. ibid., 1, 1106.

Lee, H. A., and Sharpstone, P. (1966). Haemodialysis in paediatrics. Acta paediat. (Uppsala), 55, 529.

Lieberman, E., Heuser, E., Donnell, G. N., Landing, B. H., and Hammond, G. D. (1966). Hemolytic-uremic syndrome. Clinical and pathological considerations. New Engl. F. Med., 275, 227.

McLean, M. M., Jones, G. H., and Sutherland, D. A. (1966). Haemolytic-uraemic syndrome. Arch. Dis. Childh., 41, 76.

McQuiggan, M. C., Oliver, W. J., Littler, E. R., and Cerny, J. C. (1965). Hemolytic uremic syndrome. F. Amer. med. Ass., $191,787$.

Maxwell, M. H., Rockney, R. E., Kleeman, C. R., and Twiss, M. R. (1959). Peritoneal dialysis. 1. Technique and applications. ibid., 170, 917.

Merrill, J. P. (1957). The use of the artificial kidney in the treatment of glomerulonephritis. $\mathcal{F}$. chron. Dis., 5, 138.

Merskey, C., Kleiner, G. J., and Johnson, A. J. (1966). Quantitative estimation of split products of fibrinogen in human serum: relation to diagnosis and treatment. Blood, 28, 1.

Monnens, L., and Retera, R. J. M. (1965). Varianten van het hemolytisch-uremisch syndroom bij kinderen. Maandschr. Kindergeneesk., 33, 205.

Moorhead, J. F., Edwards, E. C., and Goldsmith, H. J. (1965). Haemodialysis of three children and one infant with a haemolytic-uraemic syndrome. Lancet, 1, 570.

Moriarty, M. V., and Parsons, F. M. (1966). Intermittent peritoneal dialysis. Brit. $\mathcal{F}$. Urol., 38, 623.

Piel, C. F., and Phibbs, R. H. (1966). The hemolytic-uremic syndrome. Pediat. Clin. N. Amer., 13, 295.

Regoeczi, E., Rubenberg, M. L., and Brain, M. C. (1967). Intravascular haemolysis and disseminated intravascular coagulation. Lancet, 1, 601. 